\title{
The Role of Block Shareholders in the Relationship between Diversification and Bank Performance in Vietnam
}

Submitted 10/09/20, 1st revision 18/10/20, 2nd revision 22/11/20, accepted 15/12/20

\begin{abstract}
PHAM Quoc Viet ${ }^{1}$
Abstract:

Purpose: This paper examines the impact of diversification on bank performance and the role of block shareholders in this relationship.

Design/Methodology/Approach: Dynamic GMM estimation is applied to test the research hypotheses on the sample of 21 Vietnamese commercial banks during the 2009-2018 period. Bank performance is measured by profitability and risks, whereas diversification is measured by income diversification, non-interest income diversification and non-interest income share. The presence of block shareholders is measured by ownership ratio and a dummy variable with 10\% ownership threshold.

Findings: Income diversification enhances bank performance, whereas non-interest income share has a reverse impact. State block shareholders help amplify the positive influence of diversification on bank performance, meanwhile the roles of foreign and private block shareholders remain ambiguous.

Practical implications: Increased non-interest income share may adversely impact diversification. Vietnam should loosen the private and foreign ownership for banks so as to benefit more from diversification.

Originality/Value: The paper contributes to the literature in three main ways. Firstly, it adds empirical evidence to the effects of diversification on bank performance in a transitional economy. Secondly, this paper provides evidence for the impact of block shareholders on the relationship between diversification and bank performance in the context of privatization and increasing presence of foreign investors. Thirdly, the article adds empirical evidence to the impact of other factors on bank performance after the 2007-2009 global financial crisis.
\end{abstract}

Keywords: Income diversification, bank performance, block shareholder.

JEL Codes: G21, G28, G34.

Paper type: Research paper.

\footnotetext{
${ }^{1}$ University of Finance-Marketing, Ho Chi Minh City Viet Nam, ORCID: 0000-0002-29963850,e-mail:vietpq@ufm.edu.vn;
} 


\section{Introduction}

Competitive pressure and deregulation in the banking industry have spurred financial institutions to break out of the confinement of traditional practices and to shift into fields that yield non-interest income, including fees and commission services, bancassurance and off-balance sheet activities (Lepetit et al., 2008). There have been many studies concerning the impact of diversification on bank performance in terms of profitability and risks (Thalassinos and Kiriazidis, 2003). The positive influence of diversification on bank performance has been empirically proven through studies by, inter alia, Baele et al. (2007), Lee et al. (2014), MoududUl-Huq et al. (2018) and Doan et al. (2018). However, a number of empirical experiences show a negative relationship between diversification and bank performance, such as Berger et al. (2010) and Fang et al. (2011).

While the relationship between diversification and bank performance is a common research topic, research on the impact of ownership structure on this relationship remains scarce (Doan et al., 2018). Diversification is one type of corporate strategies, and thus, the influence of block shareholders on banks' attitudes towards risk acceptance has been theoretically ratified. Saghi-Zedek (2016) discovered a difference in diversification activity between banks with and without controlling shareholders. Berger et al. (2010) drew a comparison between diversification activity of foreign shareholders with that of domestic shareholders (including both state and private shareholders). Doan et al. (2018) contributed to previous empirical evidence with findings for an increasing effect of income diversification on performance and an adverse effect of non-interest income on performance. In addition, state-owned banks are less effective at income diversification, while foreign-owned banks in developing countries are more effective at diversification.

The transition from planned to market economy in Vietnam may have created a favorable case for research on the correlation between diversification and bank performance, as well as for research on the role of block shareholders in this relationship.

After the 2007 - 2009 global financial crisis, banks in Vietnam introduced changes in governance, most notably the ownership ratio threshold for block shareholders (The Law on Credit Institutions of Vietnam, 2010), or to be more precise, 5\% for private shareholders, $15 \%$ for organizational shareholders, except for state shareholders in state-owned banks and foreign shareholders in fully foreign-owned banks. To a certain extent, these changes may significantly influence banks' diversification activity and block shareholders' impact on this activity.

This paper contributes to the literature as follows. Firstly, it adds empirical evidence to the effects of diversification on bank performance in a transitional economy. Bank performance is examined based on two aspects: profitability and risks; whereas diversification is considered in the form of proxy income diversification, non- 
interest income diversification and non-interest income share. Secondly, this paper provides evidence for the influence of block shareholders on the relationship between diversification and bank performance in the context of privatization and increasing presence of foreign investors. The ownership threshold for block shareholders in this research is $10 \%$, as the $20 \%$ threshold adopted in past studies (for instance, La Porta et al., 1999; Doan et al., 2018) is not suitable for bank ownership structure practices in Vietnam. Thirdly, the paper adds empirical evidence to the effect of bank-specific factors and macroeconomic factors on bank performance in a transitional economy after the 2007-2009 global financial crisis.

The rest of the paper is structured as follows: in Section 2 the author briefly surveys the existing literature, highlighting the impact of diversification on bank performance and the influence of block shareholders on this relationship. Section 3 presents research methods, including research hypothesis development, data, model and research variables description, as well as data estimation methods. Research results and discussion are detailed in Section 4, conclusion and policy implications in Section 5.

\section{Theoretical Framework and Empirical Evidence}

\subsection{Diversification and Bank Performance}

According to Lepetit et al. (2008), competitive pressure and deregulation encourage financial institutions to focus on non-interest income, including fee-based and commission services activities, bancassurance and off-balance sheet activities. Diversification may have a direct influence on bank performance through the difference in profit margin from income and non-income activities, or indirectly through various diversification level of each bank regarding these two activities.

Baele et al. (2007) debated that diversification served to help banks achieve economies of scope and operating synergy. Financial conglomerates might achieve economies of information by providing an array of services for the same customer. On the other hand, the complexity of diversification intensified interest conflicts between banks and customers and among departments providing different services.

Diversification of investment categories reduces risks owing to the low correlation between income sources and their asynchronous periodic patterns (Batten and Vo, 2016). Froot and Stein (1998) concluded that diversification served to prevent default risks and abate financial exhaustion. Diversification affects bank profits and stability, as well as diminishes risks and financial exhaustion (Berger et al., 1999; Baele et al., 2007). By diversifying, banks earn less interest income and simultaneously minimize credit risks and interest rate risks (Pennathur et al., 2012). Diversification benefits financial institutions by reducing regulatory costs, improving performance and efficient application of governance skills (Boyd and Prescott, 1986; Drucker and Puri, 2009). 
On the contrary, some studies suggest that non-traditional income diversification increases income volatility. DeYoung and Roland's (2001) analysis covered a range of topics, from the fierce competition in non-interest practices and fixed costs to feebased services and lack of regulations on non-interest activities. According to Stiroh (2004), Stiroh and Rumble (2006), the strong correlation between non-interest and interest income may emerge from cross-selling different bank products to the same customer.

Thus, even though the impact of diversification on improving bank performance and reducing risks is theoretically supported, empirical evidence shows diverse results, which can be accounted for by the differences in financial innovation and financial structure in each country (Lee et al., 2014).

The majority of empirical evidence gathered from various economies in different periods endorses a positive influence of diversification on profitability. Baele et al. (2007) discovered a correlation between bank franchise value and diversification in European banks. Doan et al. (2018) confirmed a favorable relation between diversification and performance based on a sample pool of banks from 83 countries during the 2003-2012 period.

However, the authors also stated that non-interest income dwindles performance. Lee et al. (2014) examined a sample of banks from 29 Asian-Pacific countries during 1995-2009 and established that diversification improves bank performance. A study by Fang et al. (2011) on banks from 15 transitional economies in Europe during 1997-2008 concluded that asset diversification positively, whereas loan diversification negatively, correlates with bank performance. Moudud-Ul-Huq et al. (2018) investigated banks in ASEAN-5 countries (Thailand, Malaysia, Indonesia, The Philippines and Vietnam) from 2011 to 2015 and collected evidence of enhanced performance and lower risks in diversified banks.

Nevertheless, a handful of empirical studies have determined that diversification unfavorably affects bank performance. For instance, research by Berger et al. (2010) on a panel of 88 Chinese banks over the period 1996-2006 displayed declining performance, in all four aspects: loans, deposits, assets and geographic location, along with escalating diversification. Doan et al. (2018) suggested that non-interest income share slashes performance. Fang et al. (2011) gathered evidence for a negative correlation between debt diversification and bank performance.

While empirical evidence primarily verified a positive effect of diversification on bank performance, empirical studies of the connection between diversification and banks' risks yielded mixed results.

Stiroh (2004) was one of the first authors to study the effects of diversification on banks' default risk. The research results on American banking industry suggested that non-interest income share increases risks (through Z-score and Sharpe ratio), 
which is explained by the high correlation between fee income and net interest income. Goddard et al. (2008), based on a sample of American credit unions, also approved a positive relationship between diversification and risks. Molyneux and Yip's findings (2013) on diversification behavior of banks in Islamic countries determined a positive correlation between diversification and default risk, which is more clearly manifested in Islamic banks. Lepetit et al. (2008), whose study surveyed European banks, concluded that banks extending into non-interest activities suffer from higher risks and default risks in comparison with credit-based banks. Abuzayed et al. (2018) analyzed a sample of banks in six countries of Gulf Cooperation Council from 2001 to 2014 and also drew the same conclusion.

On the other hand, there has been evidence that diversification leads to reduced bank risk. Stiroh and Rumble (2006), in their study on diversification of American financial holding companies, obtained evidence for a risk-reducing quality of diversification. Köhler's (2014) research on banks in Germany, including savings banks, cooperative banks and other banks (retail- and investment-oriented) indicated that fee-based services and trading income of most banks (except for investmentoriented banks) is inversely related to risks. A study by Lee et al. (2014) on banks in 29 Asian-Pacific countries and a study by Moudud-Ul-Huq et al. (2018) on banks in ASEAN-5 countries showing that diversification contributes to risk reduction.

In addition, research by Baele et al. (2007) with a sample of listed European banks in the 1989-2004 period found proofs to support a nonlinear relationship between risks and diversification. For most banks income diversification reduces idiosyncratic risks, but it increases systematic risks.

\subsection{The Role of Block Shareholders in the Relationship between Diversification and Bank Performance}

Corporate governance is a system to ensure effective orientation and operation of the company. Shleifer and Vishny (1997) argued that corporate governance can be defined as the tool to help maximize return on investment for the company's shareholders and creditors. Thus, in theory, corporate governance can help reduce agency costs between managers and shareholders and other stakeholders, thereby affecting the company's performance.

Berger et al. (2005) used ownership structure to evaluate corporate governance, inheriting the opinion of Shleifer and Vishny (1997), due to poor legal infrastructure in protection of the investors. Block shareholders, through their voting rights, are able to influence strategic decisions of the board of directors, including decisions on diversification, with an aim to maximizing shareholder value. Berger et al. (2005) and many other authors (Pennathur et al., 2012; Saghi-Zedec, 2016; Doan et al., 2018, etc.) categorized major shareholders into three groups: state shareholders, private shareholders and foreign shareholders, depending on their distinctive traits. 
Huibers (2005) stated that in terms of state ownership, every citizen, albeit theoretically a holder, has no authority or incentive to supervise banks, which makes the government the most effective representative. Any grave agency problem shall diminish the performance of state-owned banks. Likewise, Megginson (2005) considered state ownership ineffective because it has to balance between social and economic goals and is subject to poor supervision and lack of market discipline.

Morck et al. (2000) argued that families and the state regard innovation and openness as an insidious threat to their management rights, and thus, are not willing to accept financial innovation. Meanwhile, foreign ownership in domestic banks can innovate banking services thanks to new technologies and products (Levin, 2001), thereby boosting performance.

Bonin et al. (2005) surveyed Eastern European transitional economies and drew the conclusion that foreign ownership is of the highest efficiency, followed by private ownership, and lastly state ownership, analogous with a study by Berger et al. (2005) on the banking sector in Argentina.

In contrast to ample studies on the effects of ownership structure on bank performance, research on the influence of block shareholders on banks' diversification decisions remains sparse (Doan et al., 2018). Firstly, Saghi-Zedek (2016) investigated whether the presence of a controlling shareholder makes a difference in banks' diversification behavior. From a panel of Western European banks in the period 2002-2010 consisting of two groups - diversified and nondiversified banks, he argued that diversification increases profits and risks.

Furthermore, institutional shareholders increase economies of diversification. Banks do not benefit from diversification in the absence of a controlling shareholder, or a controlling shareholder as a state shareholder or a family shareholder. Berger et al. (2010) compared the diversification behavior of foreign shareholders with domestic shareholders (including state and private shareholders). From a sample of Chinese banks from 1996 to 2006, the authors discovered that foreign ownership alleviated the negative impacts of diversification. Jiang et al. (2013) pursued the same research topic with a study on Chinese banks after privatization and attracting foreign investors in the late 1990s, thereby confirmed the poor performance of state-owned commercial banks - SOCBs), and also approved that IPO increased performance.

Pennathur et al. (2012) studied the influence of block shareholders on the relationship between diversification and bank performance in India during the 20012009 period. The authors gathered evidence of increased income diversification among banks with state, private and foreign shareholders. Diversification reduces the risks among state-owned banks but increases the risks among private and foreign banks. Meslier et al. (2014) proved that diversification in the Philippines increased profits, but higher in foreign banks. The most recent study by Doan et al. (2018) focused on a sample of banks in 83 countries in the period 2003-2012. The authors 
concluded that income diversification increases performance, and non-interest income has reverse impact. In addition, state-owned banks achieved lower efficiency in diversification than private banks, albeit with lower diversification costs. Foreign ownership achieved lower efficiency in diversification in developed countries, and vice versa in developing countries after the global financial crisis.

\section{Research Methods}

\subsection{Research Hypothesis Development}

Research hypothesis 1: Diversification affects bank performance, in which it increases profits and reduces risks.

The Law on Credit Institutions of Vietnam (2010) requires commercial banks to separate securities trading activities from bank traditional operations (including deposit-taking, credit provision and payment services). However, banks are allowed to establish subsidiaries for securities trading and assets management. Therefore, banks' non-interest income, besides fee-based services, includes income from trading and investing activities, which is highly correlated with net interest from cross-selling activities. This is extensively substantiated by previous empirical evidence, notably by Fang et al. (2011), Lee et al. (2014), Moudud-Ul-Huq et al. (2018), Pennathur et al. (2012) for state-owned banks.

Research hypothesis 2: Block shareholders affect bank performance, in which bank performance correspondingly decreases in the following order: foreign, private and state shareholders.

The Law on Credit Institutions of Vietnam (2010) regulates that individual shareholders are not allowed to possess more than $5 \%$ of shareholder equity, and more than $15 \%$ for organizational shareholders, except for state shareholders in state-owned banks and foreign shareholders in fully foreign-owned banks. Block shareholders exercising their voting rights can appoint their representatives to the board of directors and thereby orient banks' development strategies. Therefore, the proposed research hypothesis is that the presence of block shareholders affects bank performance. This hypothesis is supported by previous empirical evidence from Saghi-Zedek (2016). With a focus on block shareholder groups, the research hypothesis pursues the points of view Huibers (2005), Morck et al. (2000) and empirical evidence by, inter alia, Bonin et al. (2005), Berger et al. (2005), Jiang et al. (2013), Doan et al. (2018). It is argued that bank performance shall gradually decrease in the following order: foreign shareholders, private shareholders, and state shareholders.

Research hypothesis 3: Block shareholders affect the relationship between diversification and bank performance, in which the profits increase and risks are reduced. 
Block shareholders have the power to influence decisions of the board of directors, including diversification decisions, with an aim to maximizing benefits for shareholders. Saghi-Zedek (2016) claimed that banks do not benefit from diversification without a controlling shareholder. Although corporate governance regulations in Vietnam have only been in force since 2007, pursuant to the Law on Securities of Vietnam, the author expects a positive influence of block shareholders, at least for state shareholders and foreign shareholders, on the relationship between diversification and performance.

\subsection{Sample}

The research sample was collected from audited annual financial statements of Vietnamese commercial banks. The author excluded merged banks and banks particularly under the special control of the State Bank of Vietnam (Vietnamese central bank) and banks with insufficient data during the study period. The sample included 21 banks in the period $2008-2019$; accounting for $60 \%$ of the total number of banks and $86 \%$ of the total assets in the banking system.

\subsection{Model Specification and Variables}

The research model, derived from Pennathur et al. (2012) and Saghi-Zedek (2016), generally formulated as follows:

Bank Performance $_{i t}=\alpha+\beta_{1}\left(\right.$ Block shareholders Dummy $\left._{i t}\right)+\beta_{2}$ Diversification $_{i t}+$ $\gamma \mathrm{X}_{\mathrm{it}}+\varepsilon_{\mathrm{it}}$

Regression equation (1) is used to test research hypotheses 1 and 2. Concerning research hypothesis 3, the author followed the idea of Doan et al. (2018), in which the authors introduced an interaction variable between block shareholders and diversification, forming regression equation (2):

Bank Performance $_{i t}=\alpha+\beta_{1}\left(\right.$ Block shareholders Dummy $_{i t}$ X Diversification $\left.{ }_{i t}\right)+$ $\beta_{2}$ Diversification $_{\mathrm{it}}+\gamma \mathrm{X}_{\mathrm{it}}+\varepsilon_{\mathrm{it}}$

Bank performance measures the bank performance (profitability and risk), Block shareholders Dummy includes 3 dummy variables for state, private and foreign ownership, Diversification includes variables measuring income diversification and non-interest income diversification, $\mathrm{X}$ is a set of control variables for the bank (Bank size, equity ratio, deposit ratio, loan ratio, asset growth, listing dummy variables) and macro environment (GDP growth and inflation).

Dependent variables for bank performance, derived from studies by, inter alia, Pennathur et al. (2012), Saghi-Zedek (2016), Moudud-Ul-Huq et al. (2018), denote return on total assets (ROA), risk-adjusted return on total assets (RAROA) and default risk (ZSCORE). 
Independent variables for banks' income diversification include three proxies - noninterest income share (NIISHARE), derived from studies by Batten and Vo (2016), Baele et al. (2007), Doan et al. (2018), etc., income diversification (IDIV), and noninterest income diversification (NIDIV), derived from studies by Saghi-Zedek (2016), Abuzayed et al. (2018) and Doan et al. (2018).

Independent variables for block shareholders include two groups of variables, with the first group being the ownership ratio of the state block shareholder (SO), the private block shareholder (PO), the foreign block shareholder (FO), derived from the measurements of a study by Berger et al. (2010). The second group is the dummy variable group regarding control of state shareholders, private shareholders and foreign shareholders (DSO10, DPO10, DFO10), with a threshold of 10\%, according to Pennathur et al. (2012), Jiang et al. (2013), Saghi-Zedek (2016), etc. The author decided on ownership threshold of $10 \%$ instead of $20 \%$ (as found in studies by Doan et al., 2018, among others), as the Law on Credit Institutions of Vietnam forbids individual shareholders from possessing more than $5 \%$ of the shareholder equity and organizational shareholders from more than $15 \%$ of the shareholder equity, except for state shareholders in state-owned banks and foreign shareholders in fully foreignowned banks.

Control variables in the model include Bank Size (SIZE), Equity Ratio (EQUITY), Deposit Ratio (DEPOSIT), Loan Ratio (LOAN), Asset Growth (GROWTH), dummy variables for listed banks (DLIST), GDP growth (GDP) and inflation (INF), which have been extensively used in studies on bank performance (Berger et al., 2010; Fang et al., 2011; Pennathur et al., 2012; Lee et al., 2014; Saghi-Zedek, 2016; Abuzayed et al., 2018, etc.).

Table 1. Definitions of variables

\begin{tabular}{|c|c|c|c|}
\hline No. & Variables & $\begin{array}{l}\text { Abbreviati } \\
\text { ons }\end{array}$ & Definition \\
\hline \multicolumn{4}{|c|}{ Dependent variables } \\
\hline 1 & Return on Assets & ROA & $\begin{array}{l}\text { Measured as the ratio of profit after tax divided by } \\
\text { total assets }(\%)\end{array}$ \\
\hline 2 & $\begin{array}{l}\text { Risk-Adjusted } \\
\text { Return on Assets }\end{array}$ & RAROA & $\begin{array}{l}\text { Measured as the ratio of ROA divided by its three- } \\
\text { year rolling-window standard deviation }(\sigma \mathrm{ROA}) \text {, }\end{array}$ \\
\hline 3 & $\begin{array}{l}\text { Default Risk (Z- } \\
\text { score })\end{array}$ & ZSCORE & $\begin{array}{l}(\mathrm{ROA}+\mathrm{EQUITY}) / \sigma \mathrm{ROA} \text {, where EQUITY is the } \\
\text { ratio of shareholder equity scaled by total assets }\end{array}$ \\
\hline \multicolumn{4}{|c|}{ Independent variables for income diversification } \\
\hline 1 & $\begin{array}{l}\text { Income } \\
\text { Diversification }\end{array}$ & IDIV & $\begin{array}{l}\text { IDIV }=1-\left[(\mathrm{NII} / \mathrm{NOI})^{2}+(\mathrm{NON} / \mathrm{NOI})^{2}\right] \\
\text { Where NII, NON and NOI, respectively, are net } \\
\text { interest income, non-interest income and net operating } \\
\text { income }\end{array}$ \\
\hline 2 & $\begin{array}{l}\text { Non-Interest } \\
\text { Income } \\
\text { Diversification }\end{array}$ & NIDIV & $\begin{array}{l}\text { NIDIV }=1-\left[(\mathrm{FEE} / \mathrm{NON})^{2}+(\mathrm{TRADE} / \mathrm{NON})^{2}\right] \\
\text { Where FEE is fee income, TRADE is trading income } \\
\text { and other non-interest income }\end{array}$ \\
\hline 3 & $\begin{array}{l}\text { Non-interest income } \\
\text { share }\end{array}$ & NIISHARE & $\begin{array}{l}\text { Measured as the ratio of non-income interest (NON) } \\
\text { divided by net operating income (NOI) }\end{array}$ \\
\hline
\end{tabular}




\begin{tabular}{|l|l|l|l|}
\hline \multicolumn{4}{|l|}{ Independent variables for block shareholder ownership } \\
\hline 1 & State Ownership & SO & $\begin{array}{l}\text { The percentage of bank equity owned by state block } \\
\text { shareholders }\end{array}$ \\
\hline 2 & Private Ownership & PO & $\begin{array}{l}\text { The percentage of bank equity owned by private } \\
\text { block shareholders }\end{array}$ \\
\hline 3 & Foreign Ownership & FO & $\begin{array}{l}\text { The percentage of bank equity owned by foreign } \\
\text { block shareholders }\end{array}$ \\
\hline 4 & $\begin{array}{l}\text { Dummy State } \\
\text { Ownership }\end{array}$ & DSO10 & $\begin{array}{l}\text { Dummy variable, which takes value 1 if the state } \\
\text { ownership is above the threshold 10\%, 0 otherwise }\end{array}$ \\
\hline 5 & $\begin{array}{l}\text { Dummy Private } \\
\text { Ownership }\end{array}$ & DPO10 & $\begin{array}{l}\text { Dummy variable, which takes value 1 if the private } \\
\text { ownership is above the threshold 10\%, 0 otherwise }\end{array}$ \\
\hline 6 & $\begin{array}{l}\text { Dummy Foreign } \\
\text { Ownership }\end{array}$ & DFO10 & $\begin{array}{l}\text { Dummy variable, which takes value 1 if the foreign } \\
\text { ownership is above the threshold 10\%, 0 otherwise }\end{array}$ \\
\hline Control variables & Bank size & SIZE & Natural logarithm of total assets (billion VND) \\
\hline 1 & Equity ratio & EQUITY & Ratio of shareholder equity to total Assets \\
\hline 2 & Deposit ratio & DEPOSIT & Ratio of deposit to Total Assets \\
\hline 3 & Loan ratio & LOAN & Ratio of loan to Total Assets \\
\hline 4 & Asset growth & GROWTH & Asset annual growth \\
\hline 5 & Listed Dummy & DLIST & $\begin{array}{l}\text { Dummy variable, which takes value 1 for listed banks } \\
\text { and 0 for unlisted banks }\end{array}$ \\
\hline 6 & GDP growth & GDP & GDP annual growth \\
\hline 7 & Inflation & INF & CPI annual growth \\
\hline 8 & Own study &
\end{tabular}

Source: Own study.

\subsection{Data Estimation Methods}

According to Campa and Kedia (2002), diversification is endogenous and leads to biased data estimates. Based on a study by Abuzayed et al. (2018), by using dynamic GMM estimation, the author managed to eliminate endogeneity and violations of other regression assumptions. The selection of instrumental variables was performed under Saghi-Zedek's (2016) recommendations, namely lagged values of the independent variables and control variables, except for variables for ownership (as bank ownership is stabilized over time, as commented by Chi, 2005) and the macro environment variables are considered exogenous variables. The validity of the instrumental variables was tested by Hansen test, whereas the second-order autocorrelation of residuals was examined through Arellano and Bond test (AR2 test).

\section{Research Results and Discussions}

Table 2 presents the descriptive statistics of the variables. ROA denotes return on total assets. RAROA represents risk-adjusted return on total assets divided by its three-year rolling window standard deviation. ZSCORE is the sum of ROA and equity to total assets ratio divided by the three-year rolling window standard deviation of ROA. SO, FO, DO, respectively, are the ownership ratio of state, foreign and private block shareholders. IDIV measures income diversification, calculated by $1-\left[(\mathrm{NII} / \mathrm{NOI})^{2}+(\mathrm{NON} / \mathrm{NOI})^{2}\right]$, where NII, NON, and NOI, 
respectively, are net income interest, non-income interest and net operating income. NIDIV measures non-interest income diversification, calculated by 1 $\left[(\mathrm{FEE} / \mathrm{NON})^{2}+(\mathrm{TRADE} / \mathrm{NON})^{2}\right]$, where FEE is fee income, TRADE is trading income and other non-interest income. NIISHARE is the ratio of non-interest income divided by net operating income. SIZE is the natural logarithm of total assets (billion VND). EQUITY is the ratio of shareholder equity divided by total assets. DEPOSIT and LOAN are respectively the ratio of deposits and loans to total assets. GROWTH measures annual growth in bank assets. GDP and CPI respectively measure the annual growth of real GDP and CPI.

Table 2. Descriptive statistics of variables

\begin{tabular}{lllllll}
\hline Variable & Obs. & Mean & Median & Max & Min & StdDev \\
\hline ROA & 304 & 0.985 & 0.862 & 5.952 & -5.512 & 0.779 \\
RAROA & 266 & 5.804 & 3.931 & 53.294 & -1.467 & 6.736 \\
ZSCORE & 266 & 67.917 & 43.206 & 737.965 & 0.322 & 83.087 \\
SO & 251 & 0.274 & 0.061 & 1.000 & 0.000 & 0.360 \\
FO & 251 & 0.067 & 0.000 & 0.300 & 0.000 & 0.103 \\
PO & 251 & 0.060 & 0.000 & 0.598 & 0.000 & 0.095 \\
IDIV & 304 & 0.279 & 0.312 & 0.500 & -1.667 & 0.199 \\
NIDIV & 304 & 0.076 & 0.426 & 0.500 & -19.932 & 1.480 \\
NIISHARE & 304 & 20.347 & 19.412 & 100.000 & -54.084 & 15.121 \\
SIZE & 304 & 11.287 & 11.556 & 14.214 & 5.932 & 1.535 \\
EQUITY & 304 & 10.297 & 8.608 & 46.245 & 0.406 & 6.362 \\
DEPOSIT & 304 & 63.017 & 65.135 & 89.372 & 0.000 & 14.194 \\
LOAN & 304 & 55.313 & 56.884 & 87.972 & 11.384 & 14.163 \\
GROWTH & 286 & 0.374 & 0.185 & 8.355 & -0.392 & 0.714 \\
GDP & 304 & 6.355 & 6.423 & 7.547 & 5.247 & 0.688 \\
INF & 304 & 7.631 & 6.717 & 23.115 & 0.631 & 5.959
\end{tabular}

Source: Own study.

Statistics from Table 2 showed that the average return on total assets of Vietnamese banks was $0.985 \%$, with a standard deviation of $0.779 \%$. This is approximately equal to Indian banks' ROA of $0.99 \%$ (according to results by Pennathur et al., 2012) and much higher than that of European banks at $0.519 \%$ (according to the results by Saghi-Zadek, 2016). In addition, the average default risk measured by ZSCORE among Vietnamese banks amounted to 67.917, lower than that of Indian banks (102.72), but higher than that of European banks (54.522), respectively from results by Pennathur et al. (2012) and by Saghi-Zadek (2016).

Average ownership of state block shareholders reached $27.4 \%$, much higher than those of foreign ownership (6.7\%) and of domestic private ownership (6\%).

The average income diversification of Vietnamese banks was $27.9 \%$, and the average non-interest income diversification was $7.6 \%$. The minimum values of income diversification and non-interest income diversification were negative $(-1,667$ 
and $-19,932$ respectively), resulting from the negative income of either factor. Average non-interest income share reached $20.347 \%$.

Table 3. Block shareholders, diversification and bank performance

\begin{tabular}{|c|c|c|c|c|c|c|}
\hline \multirow[b]{2}{*}{ Variable } & \multicolumn{6}{|c|}{ Dependent variables } \\
\hline & $\begin{array}{l}\text { ROA } \\
\text { (1) }\end{array}$ & $\begin{array}{l}\text { ROA } \\
\text { (2) }\end{array}$ & $\begin{array}{l}\text { RAROA } \\
\text { (3) }\end{array}$ & $\begin{array}{l}\text { RAROA } \\
\text { (4) }\end{array}$ & $\begin{array}{l}\text { ZSCORE } \\
\text { (5) }\end{array}$ & $\begin{array}{l}\text { ZSCORE } \\
\text { (6) }\end{array}$ \\
\hline \multirow[t]{2}{*}{ L.ROA } & $0.550 * * *$ & $0.475 * * *$ & & & & \\
\hline & $(0.187)$ & $(0.158)$ & & & & \\
\hline \multirow[t]{2}{*}{ L.RAROA } & & & 0.183 & 0.495 & & \\
\hline & & & $(0.410)$ & $(0.427)$ & & \\
\hline \multirow[t]{2}{*}{ L.ZSCORE } & & & & & $0.323 * * *$ & $0.310 * * *$ \\
\hline & & & & & $(0.078)$ & $(0.055)$ \\
\hline \multirow[t]{2}{*}{ SO } & $3.074 * *$ & & 16.619 & & 87.714 & \\
\hline & $(1.435)$ & & $(10.608)$ & & $(76.335)$ & \\
\hline \multirow[t]{2}{*}{ FO } & -2.884 & & -38.149 & & -596.565 & \\
\hline & $(2.027)$ & & $(30.801)$ & & (381.006) & \\
\hline \multirow[t]{2}{*}{$\mathrm{PO}$} & $-4.792 * *$ & & $-36.463 *$ & & 977.202 & \\
\hline & $(2.105)$ & & $(20.034)$ & & $(760.768)$ & \\
\hline \multirow[t]{2}{*}{ DSO10 } & & -0.416 & & $12.876^{* *}$ & & 0.287 \\
\hline & & $(0.373)$ & & $(5.196)$ & & $(76.405)$ \\
\hline \multirow[t]{2}{*}{ DFO10 } & & 0.238 & & $-19.344 *$ & & -60.909 \\
\hline & & $(0.651)$ & & $(10.148)$ & & $(48.938)$ \\
\hline \multirow[t]{2}{*}{ DPO10 } & & -0.747 & & -7.348 & & 58.733 \\
\hline & & $(0.804)$ & & $(4.790)$ & & $(59.133)$ \\
\hline \multirow[t]{2}{*}{ IDIV } & $4.962 * * *$ & $3.058 * *$ & 13.117 & $37.456^{*}$ & 66.538 & 49.830 \\
\hline & $(1.527)$ & $(1.189)$ & $(15.130)$ & $(22.039)$ & $(719.282)$ & $(795.020)$ \\
\hline \multirow[t]{2}{*}{ NIDIV } & 0.173 & -0.125 & -0.234 & -0.410 & -55.290 & -74.954 \\
\hline & $(0.270)$ & $(0.850)$ & $(2.841)$ & $(3.311)$ & $(97.707)$ & $(81.681)$ \\
\hline \multirow[t]{2}{*}{ NIISHARE } & $-0.027 * *$ & $-0.029 * *$ & -0.109 & $-0.216^{*}$ & -2.712 & -2.471 \\
\hline & $(0.012)$ & $(0.014)$ & $(0.117)$ & $(0.115)$ & $(6.462)$ & $(9.668)$ \\
\hline \multirow[t]{2}{*}{ SIZE } & $-0.581 * *$ & -0.161 & -2.313 & -2.287 & 95.248 & $96.064 *$ \\
\hline & $(0.289)$ & $(0.247)$ & (4.663) & $(4.850)$ & $(86.228)$ & (50.333) \\
\hline \multirow[t]{2}{*}{ EQUITY } & 0.054 & -0.024 & -0.004 & -0.444 & 9.000 & 7.543 \\
\hline & $(0.064)$ & $(0.054)$ & (1.010) & $(1.252)$ & $(7.541)$ & $(7.724)$ \\
\hline \multirow[t]{2}{*}{ DEPOSIT } & $0.057 * *$ & -0.008 & 0.251 & 0.211 & -7.907 & -5.935 \\
\hline & $(0.028)$ & $(0.013)$ & $(0.176)$ & $(0.233)$ & $(8.126)$ & (9.172) \\
\hline \multirow[t]{2}{*}{ LOAN } & $-0.117 * *$ & -0.008 & $-0.782 * * *$ & $-1.006 * * *$ & 1.748 & 1.189 \\
\hline & $(0.047)$ & $(0.037)$ & $(0.294)$ & $(0.308)$ & $(4.546)$ & $(5.223)$ \\
\hline \multirow[t]{2}{*}{ GROWTH } & -0.875 & -0.384 & -12.804 & $-29.166 * *$ & 39.346 & 18.006 \\
\hline & $(0.578)$ & (1.125) & $(9.439)$ & (13.766) & (61.189) & $(47.716)$ \\
\hline \multirow[t]{2}{*}{ DLIST } & $1.377 * *$ & 0.009 & $13.134 * *$ & $13.915 * * *$ & -91.269 & -124.777 \\
\hline & $(0.589)$ & $(0.312)$ & $(5.771)$ & $(4.316)$ & (110.167) & $(82.340)$ \\
\hline \multirow[t]{2}{*}{ GDP } & $0.937 *$ & -0.045 & 1.268 & $8.600 * *$ & -5.406 & 6.528 \\
\hline & $(0.482)$ & $(0.347)$ & $(2.997)$ & $(4.209)$ & $(36.607)$ & (15.951) \\
\hline INF & $-0.060 * *$ & -0.016 & -0.331 & -0.242 & -4.849 & -0.736 \\
\hline
\end{tabular}




\begin{tabular}{lllllll} 
& $(0.026)$ & $(0.036)$ & $(0.258)$ & $(0.297)$ & $(5.900)$ & $(6.840)$ \\
Constant & 2.972 & 3.941 & 51.065 & 22.414 & -600.460 & -763.180 \\
& $(4.475)$ & $(5.122)$ & $(59.975)$ & $(64.159)$ & $(689.307)$ & $(497.095)$ \\
$\begin{array}{l}\text { Observations } \\
\begin{array}{l}\text { Number of } \\
\text { banks }\end{array}\end{array}$ & 249 & 249 & 241 & 241 & 241 & 241 \\
$\begin{array}{l}\text { AR2 test (p- } \\
\text { value) }\end{array}$ & 0.893 & 0.198 & 0.754 & 0.0838 & 0.727 & 0.497 \\
$\begin{array}{l}\text { Hansen test (p- } \\
\text { value) }\end{array}$ & 0.998 & 0.999 & 0.999 & 0.999 & 0.999 & 0.998 \\
\hline
\end{tabular}

Source: Own study.

Table 3 presents the dynamic GMM estimation results. ROA denotes return on total assets. RAROA represents risk-adjusted return on total assets divided by its threeyear rolling window standard deviation. ZSCORE is the sum of ROA and equity to total assets ratio divided by the three-year rolling window standard deviation of ROA. SO, FO, DO, respectively, are the ownership ratio of state, foreign and private block shareholders. IDIV measures income diversification, calculated by 1 $\left[(\mathrm{NII} / \mathrm{NOI})^{2}+(\mathrm{NON} / \mathrm{NOI})^{2}\right]$, where NII, NON, and NOI, respectively, are net income interest, non-income interest and net operating income. NIDIV measures non-interest income diversification, calculated by $1-\left[(\mathrm{FEE} / \mathrm{NON})^{2}+\right.$ $(\mathrm{TRADE} / \mathrm{NON})^{2}$ ], where FEE is fee income, TRADE is trading income and other non-interest income. NIISHARE is the ratio of non-interest income divided by net operating income. SIZE is the natural logarithm of total assets (billion VND). EQUITY is the ratio of shareholder equity divided by total assets. DEPOSIT and LOAN are respectively the ratio of deposits and loans to total assets. GROWTH measures annual growth in bank assets. GDP and CPI respectively measure the annual growth of real GDP and CPI. Columms (1), (3) and (5) report the regression results where ownership ratios are used, while columms (2), (4) and (6) provide the results with dummy variables for block shareholders.

Hansen test is used for testing of the overidentifying restrictions of instruments. AR2 test is a test of the absence of second-order residual autocorrelation. Standard errors are shown in parentheses. $* * *$ and $* * *$ indicate statistical significance at the $10 \%$, $5 \%$ and $1 \%$ levels, respectively.

Results in Table 3 showed that lagged values of dependent variables had a statistically significant positive correlation with the dependent variables; p-value of AR2 test and p-value of Hansen test supported the relevance of the employed instrumental variable and the absence of second-order residual autocorrelation.

Income diversification (IDIV) affected the bank performance, in which it increased the return on total assets (ROA) and risk-adjusted return on total assets (RAROA), but it was not statistically significant to default risk (positive correlation existed, but did not reach statistical significance level). This result corresponds with previous empirical evidence from studies by Fang et al. (2011) on Eastern European banks, 
by Lee et al. (2014) on Asian-Pacific banks, by Moudud-Ul-Huq et al. (2018) on banks in 5 ASEAN countries, and by Pennathur et al. (2012) on a panel of Indian banks.

However, the non-interest income share (NIISHARE) negatively impacted bank performance, in which it reduced the return on total assets and increased risks (a negative correlation with ROA and RAROA existed). This result is consistent with empirical evidence from studies by Lepetit et al. (2008) on European banks, Doan et al. (2018) on a sample of banks in 83 countries, and by Batten and Vo (2016) on Vietnamese banks.

Furthermore, the author found no evidence of the effect of non-interest income diversification (NIDIV) on Vietnamese banks' performance in terms of both returns and risks. These research results confirm the author's hypothesis 1, where it is supposed that diversification affects bank performance, and in particular increases profits and reduces risks.

State ownership increased bank profits and reduced risks, indicating a significant positive correlation between ownership ratio and return on total assets and a positive correlation between dummy variables for state ownership at $10 \%$ and risk-adjusted return on total assets. Nonetheless, the author did not find any influence of state block shareholders on banks' risks. What is more, the author obtained evidence for the influence of foreign and private block shareholders on increasing banks' risks, which was reflected in a significant negative correlation between ownership variables and risk-adjusted return on total assets. Besides, the presence of private block shareholder has a negative impact on return on total assets. This result, although contrary to author's expectations and previous empirical evidence from studies by Bonin et al. (2005), Berger et al. (2005), Jiang et al. (2013) and Doan et al. (2018), is consistent with previous results by Pennathur et al. (2012) among Indian banks. This result can be explained by the market power of state-owned banks in Vietnam: in the period 2009-2018 the total assets of four major state-owned commercial banks accounted for more than $50 \%$ of the system's (State Bank of Vietnam Annual Reports, 2009-2018), which enabled these banks to "lure" large customers, make great and stable profits, and thus, other banks were forced have to seek less potential customers and thereby suffered from increased risks and lower profit margins.

Aside from independent variables, a number of control variables actually affected bank performance. Bank size had a negative effect on return on total assets but helped reduce bank default risks. An increase in the deposit ratio positively impacted the rate of return on total assets; while the increase in loan ratio might adversely impact profits, and increase default risks among Vietnamese banks. Not only did bank assets growth did not encourage increasing profits, but vice versa. Listing promoted the improvement in bank governance, and thereby an increase in profits and reduction of default risks. Among macro factors, GDP growth contributed to 
increased profits in banks, and inflation vice versa. Next, the author examined the influence of block shareholders on the relationship between diversification and bank performance in regression equation (2).

Table 4. Block shareholders and diversification-performance relationship

\begin{tabular}{|c|c|c|c|c|c|c|c|c|c|}
\hline \multirow[b]{2}{*}{$\begin{array}{l}\text { Dependent } \\
\text { Variables } \\
\text { Variable }\end{array}$} & \multicolumn{3}{|c|}{ Income diversification (IDIV) } & \multicolumn{3}{|c|}{$\begin{array}{l}\text { Non-interest } \\
\text { diversification (NIDIV) }\end{array}$} & \multicolumn{3}{|c|}{$\begin{array}{l}\text { Non-interest } \\
\text { (NIISHARE) }\end{array}$} \\
\hline & (1) & $\begin{array}{l}\text { RARO } \\
\text { A } \\
(2)\end{array}$ & $\begin{array}{l}\text { ZSCORE } \\
\text { (3) }\end{array}$ & $\begin{array}{l}\text { ROA } \\
\text { (4) }\end{array}$ & $\begin{array}{l}\text { RARO } \\
\text { A } \\
(5)\end{array}$ & $\begin{array}{l}\text { ZSCORE } \\
(6)\end{array}$ & $\begin{array}{l}\text { ROA } \\
\text { (7) }\end{array}$ & $\begin{array}{l}\text { RAROA } \\
(8)\end{array}$ & $\begin{array}{l}\text { ZSCORE } \\
(9)\end{array}$ \\
\hline L.ROA & $\begin{array}{l}0.462 * * * \\
(0.168)\end{array}$ & & & $\begin{array}{l}0.167 \\
(0.242)\end{array}$ & & & $\begin{array}{l}0.361 \\
(0.251)\end{array}$ & & \\
\hline L.RAROA & & $\begin{array}{l}0.482 * \\
(0.248)\end{array}$ & & & $\begin{array}{l}0.383^{*} \\
(0.232)\end{array}$ & & & $\begin{array}{l}-0.223 \\
(0.334)\end{array}$ & \\
\hline L.ZSCORE & & & $\begin{array}{l}0.222 * * \\
(0.093)\end{array}$ & & & $\begin{array}{l}0.021 \\
(0.196)\end{array}$ & & & $\begin{array}{l}0.325 * * \\
(0.128)\end{array}$ \\
\hline $\begin{array}{l}\text { Diversificati } \\
\text { on x DSO10 } \\
\text { Diversificati } \\
\text { on x DFO10 }\end{array}$ & $\begin{array}{l}5.123 \\
(3.224) \\
-2.031 \\
(3.145)\end{array}$ & $\begin{array}{l}-29.226 \\
(62.812) \\
11.572 \\
(28.285)\end{array}$ & $\begin{array}{l}-550.178 \\
(651.531) \\
-757.661 \\
(626.890)\end{array}$ & $\begin{array}{l}0.524 \\
(0.819) \\
0.625 \\
(0.651)\end{array}$ & $\begin{array}{l}14.422 \\
(15.304) \\
-0.042 \\
(12.558)\end{array}$ & $\begin{array}{l}38.037 \\
(265.279) \\
-27.808 \\
(95.301)\end{array}$ & $\begin{array}{l}0.042 * * \\
(0.019) \\
0.026 \\
(0.035)\end{array}$ & $\begin{array}{l}0.884 * \\
(0.477) \\
0.317 \\
(0.229)\end{array}$ & $\begin{array}{l}-4.322 \\
(5.060) \\
-3.045 \\
(9.437)\end{array}$ \\
\hline $\begin{array}{l}\text { Diversificati } \\
\text { on } x \text { DPO10 }\end{array}$ & $\begin{array}{l}1.698 \\
(6.917)\end{array}$ & $\begin{array}{l}-11.500 \\
(25.044)\end{array}$ & $\begin{array}{l}-439.265 \\
(760.646)\end{array}$ & $\begin{array}{l}-0.704 \\
(1.107)\end{array}$ & $\begin{array}{l}-3.633 \\
(12.162)\end{array}$ & $\begin{array}{l}212.844 * \\
(110.758)\end{array}$ & $\begin{array}{l}-0.011 \\
(0.015)\end{array}$ & $\begin{array}{l}-0.291 \\
(0.290)\end{array}$ & $\begin{array}{l}-1.942 \\
(4.692)\end{array}$ \\
\hline $\begin{array}{l}\text { Diversificati } \\
\text { on }\end{array}$ & $\begin{array}{l}2.477 * \\
(1.272)\end{array}$ & $\begin{array}{l}-14.678 \\
(13.899)\end{array}$ & $\begin{array}{l}139.954 \\
(251.855)\end{array}$ & $\begin{array}{l}-0.102 \\
(0.438)\end{array}$ & $\begin{array}{l}-3.176 \\
(2.847)\end{array}$ & $\begin{array}{l}-51.618 \\
(86.593)\end{array}$ & $\begin{array}{l}-0.009 \\
(0.011)\end{array}$ & $\begin{array}{l}-0.080 \\
(0.095)\end{array}$ & $\begin{array}{l}0.608 \\
(1.963)\end{array}$ \\
\hline SIZE & $\begin{array}{l}-0.151 \\
(0.294)\end{array}$ & $\begin{array}{l}-3.175 \\
(6.961)\end{array}$ & $\begin{array}{l}-3.710 \\
(80.110)\end{array}$ & $\begin{array}{l}-0.614 * \\
(0.363)\end{array}$ & $\begin{array}{l}-5.604 \\
(8.298)\end{array}$ & $\begin{array}{l}65.346 \\
(41.837)\end{array}$ & $\begin{array}{l}0.508^{*} \\
(0.267)\end{array}$ & $\begin{array}{l}0.940 \\
(3.531)\end{array}$ & $\begin{array}{l}-14.945 \\
(69.633)\end{array}$ \\
\hline EQUITY & $\begin{array}{l}-0.050 \\
(0.072)\end{array}$ & $\begin{array}{l}-0.554 \\
(1.180)\end{array}$ & $\begin{array}{l}5.633 \\
(9.746)\end{array}$ & $\begin{array}{l}-0.021 \\
(0.056)\end{array}$ & $\begin{array}{l}-0.558 \\
(1.018)\end{array}$ & $\begin{array}{l}-0.081 \\
(10.568)\end{array}$ & $\begin{array}{l}0.118 * * \\
(0.059)\end{array}$ & $\begin{array}{l}-0.787 \\
(0.888)\end{array}$ & $\begin{array}{l}-0.144 \\
(7.444)\end{array}$ \\
\hline DEPOSIT & $\begin{array}{l}0.002 \\
(0.048)\end{array}$ & $\begin{array}{l}0.101 \\
(0.397)\end{array}$ & $\begin{array}{l}9.552 \\
(7.840)\end{array}$ & $\begin{array}{l}0.035 \\
(0.026)\end{array}$ & $\begin{array}{l}0.526 \\
(0.325)\end{array}$ & $\begin{array}{l}-6.726 \\
(8.969)\end{array}$ & $\begin{array}{l}0.000 \\
(0.018)\end{array}$ & $\begin{array}{l}-0.066 \\
(0.212)\end{array}$ & $\begin{array}{l}1.816 \\
(7.678)\end{array}$ \\
\hline LOAN & $\begin{array}{l}-0.009 \\
(0.050)\end{array}$ & $\begin{array}{l}0.102 \\
(0.244)\end{array}$ & $\begin{array}{l}-4.220 \\
(4.468)\end{array}$ & $\begin{array}{l}-0.024 \\
(0.032)\end{array}$ & $\begin{array}{l}-0.079 \\
(0.186)\end{array}$ & $\begin{array}{l}6.384 \\
(6.987)\end{array}$ & $\begin{array}{l}-0.008 \\
(0.016)\end{array}$ & $\begin{array}{l}0.122 \\
(0.521)\end{array}$ & $\begin{array}{l}-1.158 \\
(5.245)\end{array}$ \\
\hline GROWTH & $\begin{array}{l}0.148 \\
(0.627)\end{array}$ & $\begin{array}{l}-9.535 \\
(11.107)\end{array}$ & $\begin{array}{l}37.149 \\
(63.995)\end{array}$ & $\begin{array}{l}0.338 \\
(0.510)\end{array}$ & $\begin{array}{l}-3.957 \\
(7.875)\end{array}$ & $\begin{array}{l}-276.787 \\
(310.442)\end{array}$ & $\begin{array}{l}0.689 \\
(0.771)\end{array}$ & $\begin{array}{l}2.185 \\
(8.256)\end{array}$ & $\begin{array}{l}-26.425 \\
(109.237)\end{array}$ \\
\hline DLIST & $\begin{array}{l}0.417 \\
(0.528)\end{array}$ & $\begin{array}{l}15.336 \\
(11.776)\end{array}$ & $\begin{array}{l}9.368 \\
(107.817)\end{array}$ & $\begin{array}{l}1.480 * * \\
(0.613)\end{array}$ & $\begin{array}{l}15.036 \\
(14.230)\end{array}$ & $\begin{array}{l}-150.136^{*} \\
(77.760)\end{array}$ & $\begin{array}{l}0.603 \\
(0.471)\end{array}$ & $\begin{array}{l}-1.255 \\
(4.330)\end{array}$ & $\begin{array}{l}25.614 \\
(79.262)\end{array}$ \\
\hline GDP & $\begin{array}{l}0.522 \\
(0.458)\end{array}$ & $\begin{array}{l}-2.512 \\
(3.824)\end{array}$ & $\begin{array}{l}33.711 \\
(54.937)\end{array}$ & $\begin{array}{l}0.510 \\
(0.376)\end{array}$ & $\begin{array}{l}3.604 \\
(2.906)\end{array}$ & $\begin{array}{l}-38.174 \\
(64.056)\end{array}$ & $\begin{array}{l}0.004 \\
(0.147)\end{array}$ & $\begin{array}{l}-3.828 \\
(6.048)\end{array}$ & $\begin{array}{l}35.220 \\
(24.125)\end{array}$ \\
\hline INF & $\begin{array}{l}0.058 * * \\
(0.029)\end{array}$ & $\begin{array}{l}0.244 \\
(0.615)\end{array}$ & $\begin{array}{l}7.824 \\
(8.458)\end{array}$ & $\begin{array}{l}0.043 \\
(0.037)\end{array}$ & $\begin{array}{l}0.735 \\
(0.492)\end{array}$ & $\begin{array}{l}1.349 \\
(11.882)\end{array}$ & $\begin{array}{l}0.030 \\
(0.022)\end{array}$ & $\begin{array}{l}-0.032 \\
(0.273)\end{array}$ & $\begin{array}{l}1.172 \\
(8.171)\end{array}$ \\
\hline Constant & $\begin{array}{l}-0.208 \\
(2.865)\end{array}$ & $\begin{array}{l}47.374 \\
(89.625)\end{array}$ & $\begin{array}{l}-652.256 \\
(813.646)\end{array}$ & $\begin{array}{l}3.237 \\
(3.451)\end{array}$ & $\begin{array}{l}13.763 \\
(67.704)\end{array}$ & $\begin{array}{l}-261.856 \\
(332.076)\end{array}$ & $\begin{array}{l}-5.774 \\
(3.539)\end{array}$ & $\begin{array}{l}30.177 \\
(63.981)\end{array}$ & $\begin{array}{l}-89.115 \\
(1,029.175)\end{array}$ \\
\hline Observation & 249 & 241 & 241 & 249 & 241 & 241 & 249 & 241 & 241 \\
\hline $\begin{array}{l}\text { Number of } \\
\text { banks }\end{array}$ & 21 & 21 & 21 & 21 & 21 & 21 & 21 & 21 & 21 \\
\hline $\begin{array}{l}\text { AR2 test (p- } \\
\text { value) }\end{array}$ & 0.643 & 0.591 & 0.014 & 0.737 & 0.733 & 0.096 & 0.411 & 0.152 & 0.252 \\
\hline $\begin{array}{l}\text { Hansen test } \\
\text { (p-value) }\end{array}$ & 0.999 & 0.998 & 0.999 & 0.999 & 0.998 & 0.997 & 0.999 & 0.998 & 0.997 \\
\hline
\end{tabular}

Source: Own study. 
Table 4 presents the dynamic GMM estimation results from the data table. ROA denotes return on total assets. RAROA represents risk-adjusted return on total assets divided by its three-year rolling window standard deviation. ZSCORE is the sum of ROA and equity to total assets ratio divided by the three-year rolling window standard deviation of ROA. SO, FO, DO, respectively, are the ownership ratio of state, foreign and private block shareholders. IDIV measures income diversification, calculated by $1-\left[(\mathrm{NII} / \mathrm{NOI})^{2}+(\mathrm{NON} / \mathrm{NOI})^{2}\right]$, where NII, NON, and NOI, respectively, are net income interest, non-income interest and net operating income. NIDIV measures non-interest income diversification, calculated by 1 $\left[(\mathrm{FEE} / \mathrm{NON})^{2}+(\mathrm{TRADE} / \mathrm{NON})^{2}\right]$, where FEE is fee income, TRADE is trading income and other non-interest income. NIISHARE is the ratio of non-interest income divided by net operating income. SIZE is the natural logarithm of total assets (billion VND). EQUITY is the ratio of shareholder equity divided by total assets. DEPOSIT and LOAN are respectively the ratio of deposits and loans to total assets. GROWTH measures annual growth in bank assets. GDP and CPI respectively measure the annual growth of real GDP and CPI.

Columms (1), (2) and (3) report the regression results where income diversification is used as proxy for diversification, while columms (4), (5) and (6) provide the results with non-interest income diversification; and columms (7), (8) and (9) show the results with non-interest income share.

Hansen test is used for testing of the overidentifying restrictions of instruments. AR2 test is a test of the absence of second-order residual autocorrelation. Standard errors are shown in parentheses. $*, * *$ and $* * *$ indicate statistical significance at the $10 \%$, $5 \%$ and $1 \%$ levels, respectively.

Results in Table 4 suggested that state block shareholders play a role in mitigating the negative effects of diversification, as reflected in the significant positive correlation between the dummy variable for state block shareholders at the threshold of $10 \%$ and non-interest income share, where this variable has a negative impact on the return to total assets as shown above in Table 3. This result corresponds with previous empirical evidence from a study by Pennathur et al. (2012) in India, but clashes with evidence from a study by Doan et al. (2018).

Moreover, private block shareholders promote the positive impact of diversification on banks' financial capacity, through a significant positive correlation between the dummy variable for private block shareholders at the 10\% threshold with ZSCORE, however, the results in Table 3 did not indicate any influence of diversification on bank default risk. The author did not find any influence of foreign block shareholders on the relationship between diversification and performance. Given the results, research hypothesis 3 has been confirmed, at least for state block shareholders. The research results above can be accounted for by the dominant ownership ratio of state shareholders in comparison with that of private or foreign block shareholders (as presented in Table 1). Therefore, state shareholders do 
actually have an influence on the relationship between diversification and bank performance.

\section{Conclusion}

On the one hand, this research aims to examine the impact of diversification on bank performance. On the other hand, it addresses the question of whether block shareholders have any influence on the relationship between diversification and bank performance. The research results are expected to contribute empirical evidence to the literature and shall lay the foundation for policies to develop bank governance system in Vietnam.

On the research samples of 21 banks from 2008 to 2019, the author tries to answer above questions by using dynamic GMM estimation where banks revenue and risks are considered dependent variables, income diversification, non-interest income diversification and non-interest income share as independent variables for diversification, ownership ratios and dummy variables for block shareholders as independent variables for block shareholders, and the interaction between diversification and block shareholders.

Research results showed that diversification, in fact, does impact bank performance, in which diversification promotes return on assets and risk-adjusted return on assets, whereas non-interest income share has an adverse effect, which is reduced return on assets and risk-adjusted return on assets. For block shareholders, empirical findings support a positive influence of state block shareholders on return on assets, and vice versa for private block shareholders. On the other hand, the role of private and foreign block shareholders negatively affects risk-adjusted return, and vice versa for state block shareholders. The authors did not identify any empirical evidence for the influence of block shareholders on banks' default risks.

Empirical evidence for the influence of block shareholders on the relationship between diversification and bank performance remains scarce. In particular, the author only discovered a positive impact of state block shareholders on this relationship by alleviating the adverse effects of non-interest income on bank performance. Furthermore, diversification for banks with private block shareholders helps minimize banks' default risks. The author did not find any evidence on the influence of foreign block shareholders on the relationship between diversification and bank performance.

Based on the above-mentioned empirical evidence, the author recommends an easing of ownership ratio for foreign and private block shareholders so as to take greater advantage of the economies of scale and the economies of information from diversification. On the other hand, a disproportionate increase in non-interest income share may cause diversification to adversely affect bank performance, which bank management should be mindful of. 
The limitation of this study lies in the fact that the non-linear relation between noninterest income (from fee-based activities, securities trading, and foreign exchange trading) and bank performance remained unexamined. This suggests research topics to be addressed in the future.

\section{References:}

Abuzayed, B., Al-Fayoumi, N., Molyneux, P. 2018. Diversification and bank stability in the GCC. Journal of International Financial Markets, Institutions and Money, 57, 17-43.

Baele, L., De Jonghe, O., Vander Vennet, R. 2007. Does the stock market value bank diversification? Journal of Banking \& Finance, 31(7), 1999-2023.

Batten, J.A., Vo, X.V. 2016. Bank risk shifting and diversification in an emerging market. Risk Management, 18(4), 217-235.

Berger, A.N., Clarke, G.R., Cull, R., Klapper, L., Udell, G.F. 2005. Corporate governance and bank performance: A joint analysis of the static, selection, and dynamic effects of domestic, foreign, and state ownership. The World Bank.

Berger, A.N., Demsetz, R.S., Strahan, P.E. 1999. The consolidation of the financial services industry: Causes, consequences, and implications for the future. Journal of Banking \& Finance, 23(2-4), 135-194.

Berger, A.N., Hasan, I., Zhou, M. 2010. The effects of focus versus diversification on bank performance: Evidence from Chinese banks. Journal of Banking \& Finance, 34(7), 1417-1435.

Bonin, J.P., Hasan, I., Wachtel, P. 2005. Bank performance, efficiency and ownership in transition countries. Journal of banking \& finance, 29(1), 31-53.

Boyd, J.H., Prescott, E.C. 1986. Financial intermediary-coalitions. Journal of Economic theory, 38(2), 211-232.

Campa, J.M., Kedia, S. 2002. Explaining the diversification discount. The journal of finance, 57(4), 1731-1762.

Chi, J. 2005. Understanding the endogeneity between firm value and shareholder rights. Financial management, 34(4), 65-76.

DeYoung, R., Roland, K.P. 2001. Product mix and earnings volatility at commercial banks: Evidence from a degree of total leverage model. Journal of Financial Intermediation, 10(1), 54-84.

Doan, A.T., Lin, K.L., Doong, S.C. 2018. What drives bank efficiency? The interaction of bank income diversification and ownership. International Review of Economics \& Finance, 55, 203-219.

Drucker, S., Puri, M. 2009. On loan sales, loan contracting, and lending relationships. The Review of Financial Studies, 22(7), 2835-2872.

Fang, Y., Hasan, I., Marton, K. 2011. Institutional development and its impact on the performance effect of bank diversification: Evidence from transition economies. Emerging Markets Finance and Trade, 47(sup4), 5-22.

Froot, K.A., Stein, J.C. 1998. Risk management, capital budgeting, and capital structure policy for financial institutions: an integrated approach. Journal of financial economics, 47(1), 55-82.

Goddard, J., McKillop, D., Wilson, J.O. 2008. The diversification and financial performance of US credit unions. Journal of Banking \& Finance, 32(9), 1836-1849.

Huibers, F.E. 2005. Initial public offerings. The future of state-owned financial institutions. Brookings Institution Press, Washington, DC. 
Jiang, C., Yao, S., Feng, G. 2013. Bank ownership, privatization, and performance: Evidence from a transition country. Journal of banking \& finance, 37(9), 3364-3372.

Köhler, M. 2014. Does non-interest income make banks more risky? Retail-versus investment-oriented banks. Review of Financial Economics, 23(4), 182-193.

La Porta, R., Lopez-de-Silanes, F., Shleifer, A. 1999. Corporate ownership around the world. The journal of finance, 54(2), 471-517.

Lee, C.C., Hsieh, M.F., Yang, S.J. 2014. The relationship between revenue diversification and bank performance: Do financial structures and financial reforms matter? Japan and the World Economy, 29, 18-35.

Lepetit, L., Nys, E., Rous, P., Tarazi, A. 2008. Bank income structure and risk: An empirical analysis of European banks. Journal of banking \& finance, 32(8), 1452-1467.

Levine, R. 2001. International financial liberalization and economic growth. Review of international Economics, 9(4), 688-702.

Megginson, W.L. 2005. The economics of bank privatization. Journal of Banking \& Finance, 29(8-9), 1931-1980.

Meslier, C., Tacneng, R., Tarazi, A. 2014. Is bank income diversification beneficial? Evidence from an emerging economy. Journal of International Financial Markets, Institutions and Money, 31, 97-126.

Molyneux, P., Yip, J. 2013. Income diversification and performance of Islamic banks. Journal of Financial Management, Markets and Institutions, 1(1), 47-66.

Morck, R., Stangeland, D., Yeung, B. 2000. Inherited wealth, corporate control, and economic growth: the Canadian disease, in concentrated corporate ownership. In NBER Conference Volume. University of Chicago Press.

Moudud-Ul-Huq, S., Ashraf, B.N., Gupta, A.D., Zheng, C. 2018. Does bank diversification heterogeneously affect performance and risk-taking in ASEAN emerging economies? Research in International Business and Finance, 46, 342-362.

Pennathur, A.K., Subrahmanyam, V., Vishwasrao, S. 2012. Income diversification and risk: Does ownership matter? An empirical examination of Indian banks. Journal of Banking \& Finance, 36(8), 2203-2215.

Saghi-Zedek, N. 2016. Product diversification and bank performance: does ownership structure matter? Journal of Banking \& Finance, 71, 154-167.

Shleifer, A., Vishny, R.W. 1997. A survey of corporate governance. The journal of finance, 52(2), 737-783.

Stiroh, K.J. 2004. Diversification in banking: Is noninterest income the answer? Journal of money, Credit and Banking, 853-882.

Stiroh, K.J., Rumble, A. 2006. The dark side of diversification: The case of US financial holding companies. Journal of banking \& finance, 30(8), 2131-2161.

Thalassinos, I.E. and Kiriazidis, T. 2003. Degrees of Integration in International Portfolio Diversification: Effective Systemic Risk. European Research Studies Journal, 6(1-2), 119-130, DOI: 10.35808/ersj/92. 